\title{
Voluntary migrants. Indians entrusted the lost city of concepcion del Bermejo. Rio de la Plata. XVII century
}

\begin{abstract}
In this paper, we delve into the characteristics of the transfer of the residents of Concepcion del Bermejo to the city of Corrientes (River Plate) from 1630. For various reasons, including some linked to the advancement of the Chaco ethnic groups that center colonial city that belonged to the government of Buenos Aires was abandoned in the early seventeenth century. Neighbors with their families and entrusted Indians began a journey to the nearest town: Corrientes. We are interested in inquiring about the circumstances in which this mobilization of neighbors and Indians entrusted performed. We wonder among other things why the Indians accompanied their encomenderos in this transfer, rather than stay in their villages? How he received the city to which they migrated and what were the chances of insertion of the neighbors and people in a society already organized and their peculiarities? What characteristics did the lives of Indians who migrated to the new city? There are several sources located in different repositories that will bring us closer to some answers from Indian standards and neighbors, visits, capitular acts and other documents that reflect the vicissitudes and peculiarities of the transfer.
\end{abstract}

Keywords: encomiendas, ethnic chaqueñas, century XVII, corrientes
Volume 4 Issue 3 - 2019

\author{
Maria Laura Salinas \\ Professor, Doctor in History, Chair of American History, \\ National University of the Northeast, Argentina
}

Correspondence: Maria Laura Salinas, Professor, Doctor in History, Chair of American History, National University of the Northeast,Argentina, Email mlsalinas@conicet.gov.ar

Received: June 06, 2019 | Published: June 25, 2019

\section{Introduction}

One of the issues, perhaps most interesting of the colonial world Northeast current Argentine territory, is the reference to the lost city of Concepcion del Bermejo. A short time urban presence, only fortyfive, but with a rich history that has left many facets to his approach. The location of the city was designed on the banks of the Bermejo River in order to communicate Asuncion with neighboring cities of Tucuman, a pressing need at the time. The city was founded in April 1585, from the commitments made by the advanced Juan Ortiz de Zárate in the center of the Chaco region, $75 \mathrm{~km}$ from the present city of Presidencia Roque Sáenz Peña. The foundation was concretized by Alonso de Vera. From its origins faced a number of difficulties inherent in the context in which it developed: permanent advancement of chaqueños groups not subject problems for economic consolidation and commercially in the territory and even disputes with the city of Esteco for dominance of some parcels. For various reasons go deeper in which work throughout the city had to be abandoned in the first half of the seventeenth century, migrating with their encomenderos entrusted to the city of Corrientes Indians. In this paper, we delve into the characteristics of the transfer of the residents of this city from 1630 about What were the circumstances in which this mobilization of neighbors and Indians entrusted conducted? Why Indians accompanied their encomenderos in this transfer, instead of staying in their villages? How to get the city to migrate and what are the chances of integration into an already organized and their particular society? What characteristics did the lives of Indians who migrated in the new city? This lost city offers the possibility of different approaches to their study: historical, anthropological, archaeological and continues to be surprised by the interesting constantly updated data, which do nothing but demonstrate the importance of this colonial town in the regional context. With this research we want to problematize about the situation in which the transfer took place and shed new light on the relationships between neighbors and Indians in the framework of this mobilization, as well as the consequences of the installation in Corrientes for groups migrated (Figure 1).

\section{Documentary sources on concepción del bermejo}

Very few written sources that were preserved to reconstruct the years of city life, yet are useful for this work documents located in the archives of the Province of Corrientes (Argentina) in the Archives of Asuncion (Paraguay) and the Archive of Sucre (Bolivia) which will bring us closer to some answers from Indian standards and neighbors, visits, capitular acts and other documents that reflect the events and the particularities of the exodus to Corrientes. The work published more than five decades ago by José Torre Revello ${ }^{1}$ remains valid for the study of this city by the valuable documents transcribed by the author collected in the General Archive of the Indies.

Letters, testimonies of the founder of the first settlers and officials, Jesuit texts, visits of governors, among others, provide insight into the early days of settlement and disclose significant data to approach to know the life of this population redoubt. However there are many gaps appearing in the attempt to reconstruct the brief existence, so we will try to investigate some specific situations. Especially it remains in the realm of doubts the process of moving to Corrientes from neighbors and inhabitants of Concepcion, the sad walking tour, described by some sources and authors, but with many ways to deepen. They play a very interesting role the Chapter Acts of the city of Corrientes reflecting in part the impact on correntina society by receiving migrants from Concepción del Bermejo, the decisions made at the meetings on the issue and how it is preparing to receive and insert in that context villagers with all its difficulties. 


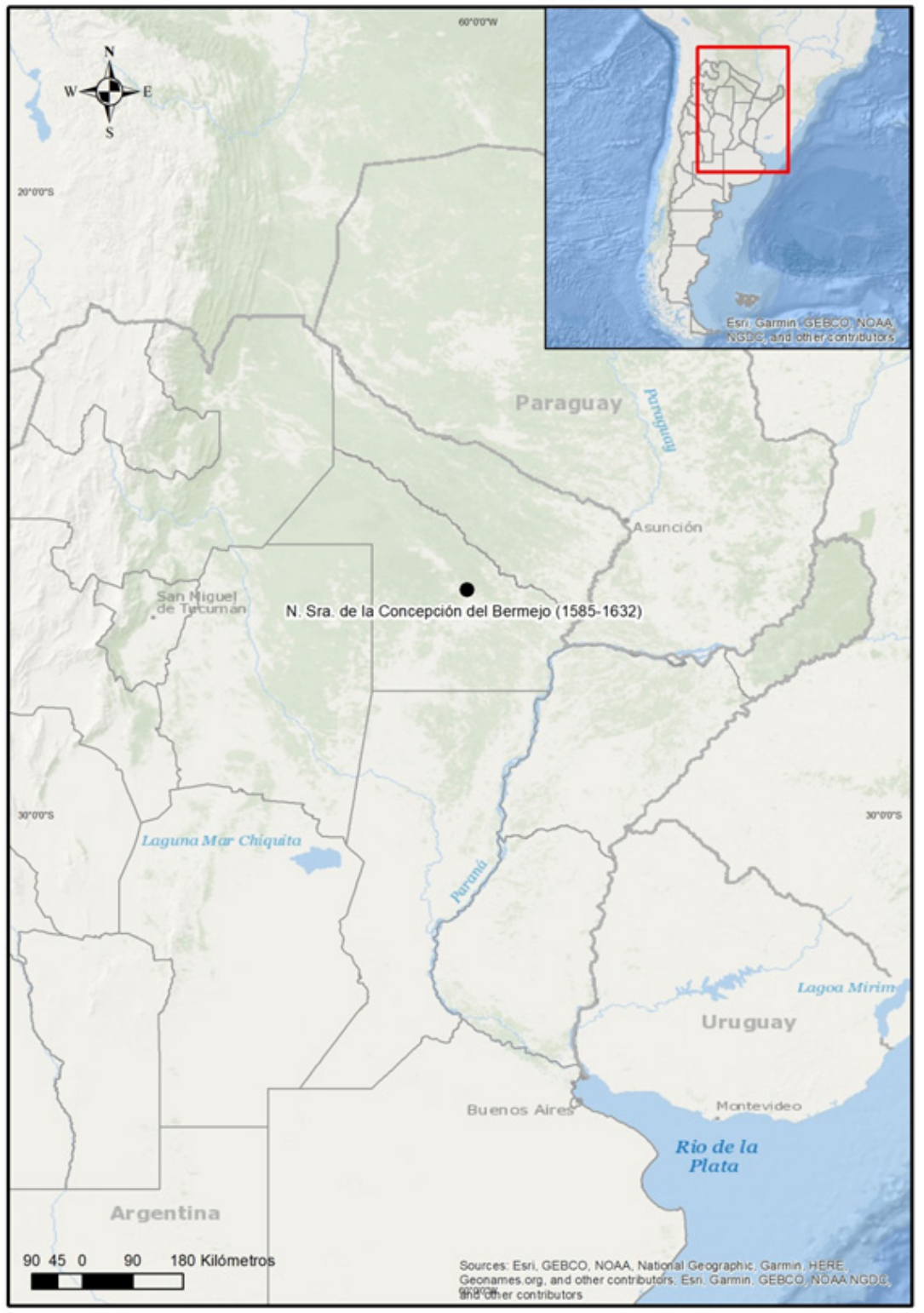

Figure I Own elaboration based on Maeder Ernesto and Ramón Gutiérrez, Historical Atlas of the Argentine Northeast.

Visits oidores made in the mid-seventeenth century to the city of Corrientes as Andrew Garabito de Leon in 1653, they also offer a very interesting descriptive overview of the situation of former neighbors and residents of the Chaco city, as well as the entrusted Indians who took refuge with their encomenderos on the nearby shore. Neighboring standards and records of seventeenth-century Indian population are also sources that allow us to reconstruct the fate of migrants installation in the new city, the population evolution and continue sequentially dimensions in the new context. The aforementioned sources as a whole help us to contextualize the panorama of the city of Corrientes in the middle of this century with the addition of the ancient inhabitants of Conception of Bermejo, although as already mentioned many aspects of the depopulated city and its inhabitants are in the field of assumptions about the lack of specific data.

For having belonged Concepción del Bermejo for governor of Buenos Aires since its organization in 1617 , will surely find in cities

${ }^{1}$ We also found in the data sources Indians and encomenderos who migrate to Santa $\mathrm{Fe}$, by also being a relatively nearby city and linked from the commercial and economical with the Asunción- Corrientes- Buenos Aires online that administratively integrated this region depopulated city emigres who tried to rebuild their lives in new scenarios. So we do not rule out future work in deeper research on sources linked to the other cities, to provide a comparative view about the reception that took the settlers with Indians and processes of adaptation and inclusion in these companies.

\section{The foundation of the city, the circumstances and the early years}

The city of Conception of Our Lady known in contemporary cartography as Concepción and Concepción de Buena Esperanza or Conception of the Bermejo River, as cited in some cases, ${ }^{2}$ was founded on April 15, 1585. One of the primary objectives of Asuncion was communication with the cities of Tucumán, its location was considered strategic for such purposes. The founder, in a letter to the bishop of Tucuman dated August 16,1585, reveals that after founding

${ }^{2}$ Sometimes, already installed in the city of Corrientes, the emigrants Indians asked about their origins, they mention that are natural Bermejo River. National Archives and Library of Bolivia. Onwards. ABNB. EC. 1653.7 
the city and be able to remove it if necessary, continued to explore the region west to meet the people of Matara, consisting of farmers Indiangroups, who lent compliance. Months later came to explore the region and found another village of the same characteristics called Guacara, whose men were subject to the regime entrusts Esteco neighbors, for this question a lawsuit with the newly founded city was then initiated. For this, Alonso de Vera, ${ }^{3}$ The work of the Indians of both peoples, would become the breadwinners of Nuestra Señora de la Concepción. In some reports from the early seventeenth century reference to the "prosperity of the city and its thriving trade with the Tucumán and the kingdoms of Peru" it is made ${ }^{4}$ Father Antonio Ruiz de Montoya showed in 1642 a memorial that "florida Concepcion was the city that had the government not only because of the importance of trade but because of the diversity of fruits". ${ }^{5}$ In fact we believe it is an overstatement by the Jesuits of the benefits of the city and we are inclined to take further reference observation governor Diego de Góngora in 1621, reflected in the document of his visit to the region. There manifested above all the fact that the Indians remain subject to the encomenderos, permanently reprising his nomadic life, relying on the Ordinances of Alfaro who in 1618 had ended (in laws) with personal service in parcels of Tucuman and Rio Plate. The inability to keep the Indians in parcels makes us suppose the difficulties in the development of agricultural and livestock activities and for the same reason we believe that although the city could find a development in some respects, was never a great flowering. ${ }^{6}$

Another document of the period states that the council asked the governor, the "King should give its people the grace to trade through the port of Buenos Aires on ships permission giving to each neighbor, the mercy of trading 500 pesos annually the products of the earth. These reports reveal an interesting livestock bighorn flow, but not market, which probably meant more difficulty at this juncture. ${ }^{1}$ The new city attended from the outset to the creation of a multiethnic society composed of a few Spaniards, as many mestizos, ${ }^{7}$ Indians entrusted with the villagers were linked, just started the installation process in place (from parcels of Matara and Guacara) and the "infidels" Indians as mentioned documents: the Chaco divided into several parcialidades who constantly threatened the city founded in this strategic territory.

Thus was established in Concepción del Bermejo a social space in the late sixteenth century and early seventeenth centuries, which came together all these actors: the residents of the new city, the small ethnic groups in villages under the encomienda system and groups

${ }^{3}$ Letter from the founder of the city of Conception of Our Lady, Alonso de Vera and Aragon, without addressee, but addressed to the Bishop of Tucuman, Francisco de Victoria in regard to the expedition for the founding of that city. August 16, 1585. Archivo General de Indias. Seville. Section I. Board. In Appendix. Torre Revello. XXV

${ }^{4}$ Information quoted Alonso de Vera Zárate cit. ${ }^{1}$

${ }^{5}$ Father Pedro Lozano in his History of the Conquest of the Provinces of Paraguay, Rio de la Plata and Tucuman repeats almost the same words Montoya: "It was the most florida, more trade and more expectation increases that took the governorship of Rio Plate, for the abundance of cotton, linen, silk, hemp and other genres that attracted merchants. ${ }^{2}$

${ }^{6}$ Ordinances hearer Francisco de Alfaro 1611, approved in 1618, ended in theory with the personal service stipulating payment for the work of the Indians, Governor Gongora refers to his visit to this as a determinant of the Indians comply with work in Concepción del Bermejo, however we have found through sources still in the mid-seventeenth century the personal service remains at cities like Corrientes and Santa Fe and the Indians know little of these ordinances.

${ }^{7}$ We know that the expeditionary contingent that participated in the foundation participated number of mestizos, although these data do not appear in the documentation. not subject not incorporated into the colonial system. Indian relations "reduced" and "low", were present, given the existing kinship ties and practices of reciprocity, redistribution and exchange. Ethnic panorama made more by chaqueños groups contributed to the difficulties for the consolidation of the city, the lifestyle and customs of huntergatherers printed special characteristics to attempts of subjugation by the neighbors and residents of the newly founded city, groups permanently returned to the nomadic life, were a continuing problem in the attempt to strengthen in the territory.

\section{A city that is abandoned}

The city during its existence, suffered serious problems: isolation and progress of the Chaco groups. From Corrientes and Asunción aid expeditions were undertaken on several occasions, but failed to achieve the consolidation by the small number of inhabitants and the aforementioned problems. The neighbors had entrusted more to chaqueñas various Indianethnic groups generally belonged to the group known as Frentones, which some documents were classified in: paguayasques, nogogayes, estuanes, Samsons, miagaylies, mogosnos, among others ${ }^{8}$ The scribe Julian Argüelles was noted that in an area of forty leagues, more than twenty "languages" spoken.

The governor Diego de Góngora in his report to the crown also mentioned similar names installments, comparable to other testimonies albeit with certain variations in spellings. Some of the informants in this period, allowing us through his writings put ourselves in the universe of Concepcion del Bermejo through their eyes, we describe difficult groups to manage, "evil Indians" in the words of the same Hernandarias. The provincial of Diego de Torres, Jesuit described as "angry people". Constantly insist on the nakedness of their bodies and disadvantages to make them work. Documents that were rescued from Cabildo de Concepción related to meetings from 1621, mention that "were incapable people, enemies of work, walking naked outside the embarrassments like the beasts, many of them eat human flesh"

Beyond own epithets observation of contemporary and period assume that the Chaco groups that surrounded Concepción del Bermejo were unwilling to yield to the presence of the settlers and their forms of resistance were felt during his period existence, to the point of collapse from 1630. Recall that the Chaco region, has always been considered untamed, with difficult Indiangroups to address, this was experienced by those who should carry out foundations in the area such as religious orders who tried to take doctrine, who only since the eighteenth century will find a more apt to meet its goals panorama. Undoubtedly came together in this context chaqueñas installments, hunter-gatherer not as likely as the Guarani to accept the reduction, the system encomenderos service to neighbors and illtreatment meted out to the Indians who managed to be reduced, which on several occasions provoked the intervention officials and rulers.

One of the best known and most significant documentation was found in the episode generated by the widow of the founder of the city Alonso de Vera: Isabel de Salazar. The encomendera faced a big fight with Hernandarias who took his commission from ill-treatment and abuse towards their charges. In this regard there is a strong testimony of the governor Diego Marin Negrón mentions that "although the Indians in the area are bellicose, are also very domestic,... but that residents of these places from Corrientes up, are as barbarians by

${ }^{8}$ Testimony of the eight Indian villages that have given peace in the Bermejo River, signed by Julian Arguelles, April 13, 1619. In: Torre Revello, 1943: Appendix $\mathrm{N}^{\mathrm{a}} 10$ : XXXI.

${ }^{9}$ Witness who answered the Cabildo de la Concepción, on 2 November 1621. Archivo General de Indias, Section V, Audiencia of Charcas. Cit. 
the little police have to make little difference with the Indians, and they are as far apart as governors use of the Indians... more than his Majesty sends" 10 Maltreatment and abuse by some neighbors to the reduced Indians impossibilities submit more numerous and permanent progress by unreduced be factors that together will complicate the possibilities of development and permanence of Conception of Bermejo in the context of governance from Buenos Aires.

Attacks by Indians under colonial cities raise the King made repeatedly by the authorities of the affected populations complaints and requests for weapons for offensive war against the Indians. Special permission to the cities of Concepcion and Asuncion to prosecute and severely punish those that would attack was granted. In this decision some authors as Torre Revello, are the main reason for the future abandonment of the city. With permission granted neighbors they did not hesitate to apply harsh punishments under which the Indians did nothing but promote leaks in and out. However in this context the problem is not dimensioned, the council of Concepcion mentioned that the decrease was due to mandated Indians who had brought in large numbers to form reductions. ${ }^{11}$ In this context it is assumed that the inhabitants of the city and its authorities could not solve the problem of labor through the charges and in turn the Indians of Matara and Guacara were not enough to sustain the economy and domestic needs the village.

$1630 \mathrm{~s}$ initiated the villagers, after several attacks chaqueños, undertook an exodus towards the city of Corrientes who received incorporating them into their society and its institutions. According to the documentation, in January 1633 the city was voluntarily depopulated by the residents to the threat of advancing two thousand tocagües Indians, ohomas, vilos and colastinés, groups that had previously attacked the village of Matara and that they had guaycurúes subsequently joined. Father Antonio Ruiz de Montoya describes the vicissitudes suffered by the residents of Concepcion at this crucial time. Reports that the Spanish people collected all in a convent of religious, until they escaped to start the walk to Corrientes flight. Hunger and desolation were the framework in which the transfer took place. "A caravan of hungry and half-naked hastily ran their way to Corrientes, where they arrived shortly thereafter, quickly spreading throughout the government the sad news of his misfortunes" is described. $^{2}$

\section{Repopulation attempts}

While there were several expeditions tried to help the city since 1629 , when Indianadvances were renewed; the governor of Buenos Aires Pedro Esteban Davila shall assess the problem and try to reconquer the territory. At first the abandonment of the city was not as definitive and took a number of actions were initiated with a view to recovery. Who they had played in specific roles in Concepción petitioning the governor had early repopulation and cars reviewing how they should recover the area. ${ }^{12}$ At a meeting of the town council of Corrientes of 1 December 1636 General Davila Enriquez explained the difficulties that arose to repopulate the city of Concepcion, mentioned that he could not punish the Indians who attacked the city, especially because of the lack of men and the costs and work

\footnotetext{
${ }^{10}$ Letter Diego Marin Negrón. January 8, 1612 cit.

${ }^{11}$ Testimony of the Cabildo de la Concepción, 2 November 1621, annexed to the Charter of Gongora. Cit.

${ }^{12}$ Attorney General's request Concepción del Bermejo Governor Dávila Enriquez. November 24, 1636 National Academy of History. Tomo I. 15881646.Buenos Aires, Kraft, 1942. pp.333. ANH hereinafter. Ctes minutes. ${ }^{3}$
}

involved assembling forces to take the entrance at that time suggested that cooperation be requested to Paraguay for the expedition. ${ }^{13}$ The possibilities for starting the reconquest of the territory were becoming increasingly difficult without being able to achieve it. It was gradually gaining more strength the idea of depopulation and final annexation of the settlers and Indians entrusted by Corrientes, mainly.

The documents reveal interesting stories of Indian life and neighbors who migrated and settled on the nearby shore. Beyond the good reception of the correntinas authorities and villagers, there were notorious difficulties in this embodiment. In January 1634 session of the Council of Corrientes, are organized to build a strong, due to rising population and Indians with the inhabitants of Concepcion and obstacles to fend off the assaults and dangers of the city. Even the need to protect "the evil neighboring towns of Concepcion," we figure that reflects the landscape of conflicts caused by the relocation and installation in Corrientes, mentioned. ${ }^{14}$ We wonder how the emigrants were in Corrientes, which in this period has not yet offered an economic development that would encourage or provide opportunities to groups arrived. However it is seen mostly in the decisions of the council an effort to contribute to a better adaptation, with some measures showing solidarity to the situation. For example the residents of Concepcion allows vaquerías to resolve when traversing remember that the benefit of these activities I had only the largest accionero, at that time, Manuel Cabral de Alpoin, whom the governor had come into conflict, since this did not allow the exploitation of livestock by these people, even in these circumstances. ${ }^{15}$

\section{Demographics of concepcion del bermejo: neighbors, encomenderos and Indians}

We can not provide precise data on the number of settlers and Indians who made the exodus to Corrientes, we have identified through subsequent sources to move, some families originated in the "Rio Bermejo" as it appears in the documentation and from these data to try to deepen their stories. Our approach will therefore be more qualitative than quantitative. Some data of the population that inhabited the Chaco city, while it existed, give us some ideas of dimensions. Diego de Torres, provincial of the Jesuits, mentioned that in 1609 the Conception had 70 neighbors whom 25 were encomenderos. Gongora 81 neighbors registered as a resident in 1622 and Francisco de Céspedes (governor of Buenos Aires) in 1628, stated that the city had 100 men, a figure which at the time was only surpassed by Buenos Aires. ${ }^{16}$ With regard to the Indianpopulation, Vera and Aragon mentioned figures close to twenty thousand Indians were supposed nominally distributed among the residents of the new city as was customary in the foundations that were made. more apparent than real because of the difficulties involved in parcels submission concessions.

Hernando Arias de Saavedra 600 Indian identified different nations reduced spread over several trustees. ${ }^{17}$ In 1611 , the governor of Buenos Aires, Diego Marin Negrón, mentioned that yanaconas Concepcion

${ }^{13}$ ANH. Ctes minutes. January 16, 1634. National Academy of History. Volume I. pp 282.

${ }^{14} \mathrm{ANH}$. Ctes minutes. 1 December 1636.pp.335-338

${ }^{15}$ ANH. Ctes minutes. August 24, 1636.pp.399.

${ }^{16}$ Francisco de Céspedes letter, Buenos Aires, September 20, 1628. In: Enrique Peña, Don Francisco de Céspedes (1624 to 1632) pp.164-167, Buenos Aires, $1916 .^{4}$

${ }^{17}$ Letter from Governor Hernando Arias de Saavedra, Buenos Aires, May 4, 1607 Journal of the National Library, Volume I, Number I, January-March, pp.131 to 139.Buenos Aires, 1937. 
amounted to add 300 and four leagues from the Indian town of Matara where there were other 350 was, which in total amounted 650 Indiansubject. The same Marín Negrón 6000 Frentones reported that Indians had "infidels" who were entrusted to Concepcion, but nominal basis since reference was made immediately they had no priests, so it was difficult to keep. These data will only help us get closer to the Indianpopulation dimension in different circumstances that accompanied the life of the city, remember that there were permanent leaks and pressure from non-subject who sought possibilities for the consolidation of the colonial city center. Here are the data of the Indians subject to the charges as recorded by the visit of Diego de Góngora, very detailed data for the period (Table 1).

Table I Population in C Bermejo entrusted by the visit of Diego de Gongora I62I

\begin{tabular}{llllll}
\hline Village & Encomienda & Women & males & minors & Total \\
\hline Will kill & Real Hacienda & 70 & 76 & 137 & 283 \\
Will kill & Isabel de Salazar & 178 & 176 & 284 & 638 \\
Guacara & Anton Martin de Don Benito Gaspar de Cequeira & Four, Five & 51 & 58 & 154 \\
Houses and farms & & 119 & 188 & 92 & 399 \\
Total & & 412 & 491 & 571 & 1474 \\
\hline
\end{tabular}

Source: List of Gongora's visit. In: Enrique Peña, op cit. pp. 187-189.

This thorough search, becomes one of the most specific we have about the city, offering a larger population when compared with data that were recorded for Corrientes in the same visit resulting in a total of 891 people: 293 adult males, 292 women and 306 children of both sexes. ${ }^{18}$ Gongora describes the case of Corrientes "No cacique with his vassals was free; all belonged per parcel to a neighbor feudatario Corrientes or crown. The community was the social regime under discretionary government doctrinante pastor. "The largest number of commissioned recorded by Gongora in Conception of Bermejo reflects us, perhaps greater prosperity relative to its neighbor at that time because of the amount of labor which implies the existence of the charges, although probably Corrientes for having Guarani parcels made up greater extent, achieved greater stability among the Indians subject.

\section{Destiny and daily life of migrants}

One of the questions we try to answer in this paper was referring to what characteristics had the lives of Indians who migrated in the new city? And especially why they had joined in the move to their

Table 2 Indians Concepción del Bermejo registered parcels. Corrientes I653

\begin{tabular}{|c|c|c|c|c|c|c|c|c|c|}
\hline Encomendero & Title & Tribe & Muja & Children & girls & Reser & Aus. & Huerf & Total \\
\hline Anton M D. Benito & Do not & 16 & 17 & 13 & 9 & 3 & - & - & 58 \\
\hline Juan de Toledo & Yes & two & 3 & 3 & 3 & one & - & - & 12 \\
\hline Gabriel Lopez de Arriola & - & two & 3 & one & - & - & - & - & 6 \\
\hline Juan de Velazco & Do not & 3 & one & two & - & - & - & - & 6 \\
\hline Lorenzo de Medina & Yes & one & one & - & - & - & - & - & two \\
\hline Ines de Luján & Yes & 4 & 3 & 5 & one & - & two & & 13 \\
\hline
\end{tabular}

Source:ABNB. EC 1653.I I Visit Leon Garabito to Corrientes

On this visit tax they introduced their families (women and

\footnotetext{
${ }^{18} \mathrm{An}$ idea of the population is entrusted in Corrientes in 1609 anua letter P. Diego de Torres: "The seven Spaniards have 60 Corrientes. Many Indians do not have peace ... "In Carlos Leonhardt ,. "Jesuitical establishments in Corrientes and Entre Rios." In BIIH. Aires.1932 good. T. XIX, p.16. Indians entrusted figures in the relationship of Governor Gongora. Emilio Ravignani. "The indigenous population of the regions of Rio de la Plata, Tucumán in the second half of the seventeenth century" in Proceedings and scientific work of the XXV International Congress of Americanists (La Plata, 1932), Bs. As, 1934, t. II, pp. 294-295.
}

encomenderos. From visits and subsequent records we can provide some answers trying to understand the situation they lived as a society and the impact of losing their land and the life they had managed to organize. Here are some data that reflect the situation of Indians and encomenderos entrusted once reached Corrientes (Table 2). Table reflect some existing parcels in the city of Corrientes in 1653 after the visit of Andres Garabito de Leon, hearer of Charcas and acting governor of Paraguay; the official toured the country trying to verify the status of entrusted, especially compliance with ordinances hearer Francisco de Alfaro. In the registration he collected, first protoestadística source type for the region, cases of Indians who belonged to the depopulated Conception who had taken refuge with their encomenderos appear clearly in this city. Depending on the data we made some estimates calculations, considering that when the record was made twenty years had passed the abandonment of the city, many of the migrants were children. Consign four trustees who belonged to Concepción del Bermejo who emigrated with his charges Indians: Anton Martin of Don Benito, Andrés López de Arriola, Juan de Toledo and Ines de Lujan and two other cases were also selected because the Red Indians. children), revealing a larger number of members in each of the parcels. The visit by the same judge in Santa Fe for example, recorded only tax. In the case of Anton Martin Concepcion neighbor of Don Benito we noticed a significant amount of tax with their families as they recounted the visit moved from "the Bermejo River". In this case it is assumed that this encomendero could be organized in the twenty years that had passed since the transfer with Indians, making keeping with various activities, in other cases they mention that the Indians had to find other people with whom to work. This neighbor even 
participated in the council, which indicates incorporation into society and institutions. ${ }^{19}$ Regarding the titles of the trustees, of the fifteen parcels visited in Corrientes nine trustees had their titles in order ${ }^{20} \mathrm{Six}$ encomenderos not presented for various reasons. Gabriel Lopez and Anthony Martin of Don Benito had delivered mentioned that according to an ordinance of the Governor Jacinto de Lariz, we note this in particular because the latter belonged to Concepción del Bermejo. ${ }^{21}$ Another important group of Indians who belonged to Concepción, were in a position to contract or "in concert" with residents of the city, a total tax twenty, some with their families were a total of fifty- six persons in this situation in Corrientes in 1653 . The peculiarity of these Indians as in other cities like Santa Fe for example, is generally belonging to other Indian towns or cities in different circumstances and had reached Corrientes and had arranged with local residents. Of tax twenty four belonged to Concepción del Bermejo, one the people of Matara, nine were from Paraguay (from different people) two of Corrientes, one of Tucuman, one of Santiago del Estero and three of Brazil. The reasons why they were in Corrientes were mixed, then specifically analyze these circumstances (Table 3 ).

Table 3 Indians live in Corrientes emigrated from Concepción del Bermejo

\begin{tabular}{|c|c|c|c|c|c|c|}
\hline In charge & Tribute & Origin & Encomendero & Muj & Children & Total \\
\hline Luis Arias (Vicar) & one & C .of Bermejo & & - & - & one \\
\hline Hernando de Alarcón & one & C. Bermejo & - & one & 4 & 6 \\
\hline Sebastián Pintos & one & will kill & Enc. King & one & two & 4 \\
\hline Manuel Cabral & one & $\begin{array}{l}\text { I Itapé Women Nacion } \\
\text { Niqueamala }\end{array}$ & - & one & 3 & 5 \\
\hline Anton Martin on behalf of the Trustee & one & Concepción del Bermejo & Convento San Francisco & - & - & one \\
\hline Total & 5 & & & 3 & 9 & 17 \\
\hline
\end{tabular}

Source:ABNB. EC 1653. I I. Leon Garabito visit to Corrientes

The table reflects the Indians called "concerted" or "concert" were not legally granted in encomienda, but worked for some time with different neighbors, varied tasks, should pay them for their work, as established Ordinances Alfaro. Some Indians were natives of places far away from Corrientes. So we could track there are numerous cases of migrant Indians of the former Jesuit towns of Guayrá or first Villarica, in addition to those of the Bermejo River area. The stories, it is clear that the path taken by these Indians, in some cases was extensive, unable to settle, forming a family, or should leave in many cases transfers and itineraries that are involved involuntarily. We mentioned earlier that we address in the box register only cases of Indians who mentioned being natives of Concepción del Bermejo and have migrated at the time of abandonment of the city. Particular stories that help us reconstruct and understand the impact of moving in different situations described are lived. "... he said he was born and native of the Bermejo River when it was depopulated stay four or five years ... and after depopulation wandered in different fields of the city and came to settle with Captain Pedro Gomez and then at home vicar where it has less than a year that is "..."22

\section{In the task of Anton Martin entrusted recounted}

"... said their origin and nature was in the Red River and the depopulation and killing that made the guaycurúes... came very small and remain in this city... and as to the ordinances have not heard from her nor the they have suggested and have only served their encomendero in everything he has commanded you"23 dAs reflected in these testimonies, in some cases they had migrated together with

${ }^{19} \mathrm{He}$ was appointed to hold the office of attorney general of the city. January 4, 1653. Proceedings Ctes. Tomo II. pp. 315

${ }^{20}$ When they had expressed their titles in rule refers to that exhibited before the visitor, do not mention anything about the actual confirmation of the same ${ }^{21}$ Governor Jacinto de Lariz apparently took with him several titles in order to achieve real confirmation. This issue seems to have been of great importance to the governor, because in the city of Santa Fe in 1653 left most of the vacant parcels for lack of confirmation. (Areces, 1999: 39)

${ }^{22}$ Father Luis Arias visit in his name did Pedro Perez de Castro. ABNB. EC. 1653.11

${ }^{23}$ Diego Rodriguez made demonstration. ABNB. EC. 1653.11 their encomenderos, in others they did alone, including surely in the group departed when the city was abandoned and upon arrival were arranged to perform various works with the residents of Corrientes . Let us not forget kinship relations that existed between the inhabitants of these colonial centers, some residents of Concepción were greeted by relatives who accompanied them on this occasion, and many of the Indians who brought were arranged with relatives of Corrientes. Some examples in the documentation in which the Indians relate the death of their encomendero in the pre-departure city and subsequent transfer with relatives of the wife of his encomendero clashes are offered. ${ }^{24}$ Situations in which the Indians were moving from one city to another, serving different encomenderos, also changing their legal status and their work conditions are observed in the sources.

"...said it is natural Village of Matara and is chief of the charge of the king and his subjects depopulation were lost... and has four years is... with Sebastián Pintos and giving you every year what is necessary... " 25

This case is interesting because the chiefs should not work for or neighbors encomenderos, under the law, according to the story to the transfer occur, he lost members of their partiality and began a life in Corrientes as a common Indian. Recall that the chiefs have always maintained a different status who was respected by officials as doctrineros so in the context of reductions. ${ }^{5}$ This is a clear example of the itinerary that followed many of these Indians live, working for different neighbors, while modifying their family and kinship ties. These cases reveal not only geographic mobility rate by these Indians but also in terms of their legal and social situation. Indians being granted parcels and to live in towns, happened to be originating or yanaconas to abandon the regime of community to live in the farms of their encomenderos or in town with a neighbor who hired them. Some authors speak of this process as a "yanaconización of mitayo"26 It should be noted that these changes in the situation, did not go unnoticed in the eyes of the monarchy, were held within the

\footnotetext{
${ }^{24}$ Visit of John Dias. ABNB. EC. 1653.11

${ }^{25}$ Demonstration made Sebastián Pintos. ABNB. EC. 1653.11

${ }^{26}$ Juan Carlos Garavaglia see domestic market ...
} 
framework of existing institutions and were recorded in the controls that undertook the Court, as in the case of visits and records of governors.

One aspect that seems relevant to point out is who the neighbors who hire these Indians. In the case of Corrientes we find people who could not access parcels by legal means, not to be meritorious or descendants of them, why, the contract system or concert favored them to access labor. We have found cases of Portuguese based in Corrientes using these practices are not entitled to parcels. ${ }^{27}$ We also found Indians Concepción del Bermejo situation in Corrientes in charge of religious or deposit. An interesting testimony it provides a resident in the convent of the Franciscans, who claims to have also been in Concepción del Bermejo in the "convent that was in the Bermejo River" Indian. ${ }^{28}$ According to the data presented in this document was at the time of arrival of the visitor about 63 native Indians of Concepcion del Bermejo, an estimate was made without regard to the children of these Indians as they surely were born already in the city Streams

\section{Some final notes on the emigrants of concepcion and its insertion in corrientes}

After completing a brief tour of the history of Concepcion del Bermejo in place of Chaco, difficulties in its short existence and its inability to establish itself as colonial city center, we want to identify some specific issues that are displayed after the transfer of neighbors and entrusted Indians. We believe that the situation did not accompany the process that he lived in this city, if at first the authorities struggled to regain territory, the lack of men and necessary elements to act were overshadowing hopes for restocking. We are not against the case of a city who moved from site, like Santa Fe or San Miguel de Tucuman, and inserted into another physical space. This is the case of an abandonment, an exodus of all the inhabitants due to the inability to continue receiving advances ethnic groups surrounding the town and not have the efficient support of the authorities, who failed in various entrances to the region. Spatial mobility of the population will become the only way to solve the problem that ailed as a society.

We wondered why the Indians subjected accompanied their encomenderos in this process. We believe that beyond the use of labor in abusive cases, the withdrawal of men from their families, and all known negative aspects of the task, the system of community that meant working his plot of land, have some animals and tools, assuring them live sometimes better than the free Spaniards. To this must be added the progress of the Indians not subject to provoke interethnic conflicts to confront difficult for those who had already adopted new forms of life related to agriculture and other customs. It will kill for instance had received several attacks that prevented its continuance as a people. ${ }^{29}$ With regard to the inclusion of these Indians in Corrientes,

\footnotetext{
${ }^{27}$ The cases of Luis Gómez, Sebastián Pintos, Juan de Carballo and Manuel Cabral (Mantilla, 1929: 82)

${ }^{28}$ Demonstration did Captain Anton Martin. ABNB. EC. 1653.11

${ }^{29} \mathrm{We}$ are taking as an example a fact that we provide the Proceedings of Indigenous Council of Itati the late eighteenth century, has nothing to do directly with what we are presenting but perhaps can guide us in trying to understand this situation. It mentioned that it was contrary to the abolition of the community and so stated to the viceroy, stating that, at first, when they were told that the Indians would be free like the Spaniards, treated as such and owners dispose of their assets He amazed them the news, but then, seeing the unfortunate fate of the Spanish farmers, preferred to remain in community. the report also exposed the miseries of the Spaniards, who did not even have to bury their dead; Instead, they, in community, never lacked anything and they always had their ration of meat, herbs, salt.Old agreements Cabildo of Itati. General Archive of the Province of Corrientes. Corrientes, Printer, 1930, pp. $156-159 .^{6}$
}

work and life forms We identified some irregularities and practices in their daily lives that were expressed by the same victims. Indians entrusted distinguish, Indians concert situation or contract, deposit Indians, vacancies and various irregular situations. The tasks fulfilled since they arrived were different, specifically related to personal and domestic services, as well as work in agricultural, livestock tasks. Since the council sometimes use permits were granted to Indians Bermejo Concepcion in various activities. ${ }^{30}$

Specific claims presented these Indians in the case of the visit of the hearer that serves as a reference, they allow us to visualize the main problems about work and relationships. Refer to the following topics: unlimited service time, permanent problems since living with encomendero or neighbor who hired and shared the everyday space (house, the farm), the neighboring Indian uses all the time. The Indian peoples and reductions (mitario) not escaped this type of service at the time mita, which usually extends over the provisions of the

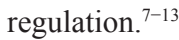

Others mentioned disadvantages are: poor treatment, corporal punishment, little food, allegations of verbal abuse and work on religious holidays. All these complaints are very common in the documentation. It is identified in the case of Indians Concepción work with different neighbors and encomenderos, as a result of its incorporation into the city. Itineraries, trips and experiences that reflect the particular situation of these "added" to the correntina life of the first half of the seventeenth century Indians. One concern was whether the visitor knew the ordinances service time and rate and tried to explain to each of the Indians who conversed on this issue. During the visit to the task of Anton Martin of Don Benito, the inspector stated: “.... his mercy sought to imply the ordinance by the king who reduced the rate two months of service. Because their parents and those who would accommodate it, could do it, and if escogiesen pay that tax on gender, it could do, and paid the mita of said two months if they also wanted to confer with other Spanish they could do, paying twenty pesos and feeding them... "311

\section{The Indians listened attentively and responded to the visitor}

"... they wanted to continue as usual here have done, serving his encomendero whose farm villages are without news..." In this regard the inspector found irregularities in compliance with ordinances. Indianserved all year without knowing that the service time was reduced. Finally it should be mentioned the inclusion of women and children in the system of work for the encomendero, the case of women deserves attention in this context, although not part from the legal point of view parcels, are found in all cases in domestic service or performing work for encomenderos spinning. Anyway, the number of Aboriginal migrants reflected in the sources we consulted in Corrientes not exceed $10 \%$ of registered voters by Governor Góngora in 1622, which tells us little quantitative dimension, but can be enhanced with data migrants Concepcion they may have gone to Santa Fe, Paraguay or to distant Buenos Aires, since, as we said earlier, the economic development of Corrientes was just emerging in this period. ${ }^{14-18}$

With respect to the inhabitants of the abandoned city, although described in the sources difficult times during transport and early installation since the mid-seventeenth century, are found participating ${ }^{30}$ They are very common at meetings of the council grants permission to use Indians in various tasks: parts of houses in the city, buildings, crops or work in the collection of maroons animals. At its meeting of 15 April 1637 it resolved to employ Indians Conception in parts of the town hall. ANH. Ctes minutes. Volume I. pp. 358.

${ }^{31}$ Visit Anton Martin de Don Benito. ABNB. EC. 1653.11 
in decisions, with positions in the council, with Indians to their service, which implied a certain welfare, it correntina apparently assimilated by the society of the time. Undoubtedly the impact of abandoning their farms, homes and belongings be affected for many years in the lives of migrants, we must continue monitoring sources to deepen in some cases and know more deeply the meaning of this circumstance in shaping correntina of society.

\section{Acknowledgments}

None.

\section{Conflicts of interest}

Author declares that there is no conflict of interest.

\section{References}

1. Torre Revello José. Esteco and Concepción del Bermejo. Two missing cities. Peuser: Buenos Aires; 1943.

2. Lozano Pedro. History of the Conquest of the provinces of Paraguay, Rio de la Plata and Tucuman. National Academy of History. Buenos Aires: Ernesto Maeder preliminary study; 2010.

3. National Academy of History. Chapter Acts of Corrientes. Ricardo Levene warning. Introduction of Hernán F Gómez. Buenos Aires. 19411946. Volume I (1588-1646); Volume II (1647-1658); Volume III (16591666); Volume IV (1667-1676).

4. Peña Enrique. Don Francisco de Céspedes (1624-1632). Buenos Aires; 1916.

5. Susnik Branislava. Indian colonial Paraguay. Asuncion, Andrés Barbero Ethnographic Museum, Volume I; 1965.

6. Old Agreements Cabildo Of Itati. General Archive of the Province of Corrientes. Corrientes, Printer; 1930.
7. Areces Nidia. Power and society. Santa Fe la Vieja. 1573-1660. Santa Fe School of History, National University of Rosario. 1999.

8. Arretx C, Mellafe R, Somoza J. Historical Demography in Latin America. Sources and methods. Costa Rica: Celade, Series E, 1002, San Jose; 1983

9. Garavaglia Juan Carlos. Internal market and colonial economy. Mexico: Grijalbo; 1983.

10. Leonhardt Carlos. Jesuitical establishments in Corrientes and Entre Rios. Buenos Aires: Bulletin of the Institute of Historical Research, Faculty of Philosophy and Letters of the UBA, T. XIX; 1932.

11. Lorandi Ana Maria. The personal service as destructuring agent in colonial Tucumán. Andean magazine. 1988;6(1):135-173.

12. Lozano Pedro. Corográfica Description Gran Chaco Gualamba, etc. Reissue by Radames Altieri, Tucuman, UNT; 1941.

13. Maeder Ernesto. Economic History of Corrientes in the colonial period. 1776-1810. Enrique Barba warning. Buenos Aires: National Academy of History; 1981.

14. Maeder Ernesto. The foundation of Corrientes. Men and circumstances (1588-1618). Revista Nordeste, Northeastern University; 1999.

15. Mantilla Manuel F. Historical chronicle of the province of Corrientes. Buenos Aires: Tomo I; 1929.

16. Ravignani Emilio. The indigenous population of the regions of Rio de la Plata, Tucumán in the second half of the seventeenth century. Proceedings and scientific work of the XXV International Congress of Americanists; 1934.

17. Salinas Maria Laura. Colonial domination and indigenous labor. A study of the charge in colonial Corrientes. Asunción, CEADUC; 2010.

18. Sanchez Albornoz Nicolás. The population of Latin America since preColumbian times to 2000. Alliance: Madrid; 1973. 